\title{
Experimental models of scald burns. A scope review ${ }^{1}$
}

\author{
Taís Amadio Menegat' (D) , Andrea Fernandes de Oliveira" (DD , Michelle Gioia Coiado Majewski"l' (DD, \\ Leila Blanes" (D) , Yara Juliano'v (D) , Neil Ferreira Novo'v (D) , Lydia Masako Ferreirav (D)
}

' Fellow Master degree, Postgraduate Program in Translational Surgery, Division of Plastic Surgery, Department of Surgery, Universidade Federal de São Paulo (UNIFESP), Brazil. Conception and design of the study; acquisition, analysis and interpretation of data; technical procedures; manuscript preparation and writing.

"PhD, Health Sciences, Postgraduate Program in Translational Surgery, UNIFESP, Sao Paulo-SP, Brazil. Conception and design of the study; acquisition, analysis and interpretation of data; manuscript writing; critical revision; final approval.

II'Graduate student, School of Medicine, PIBIC/CNPq, UNIFESP, Sao Paulo-SP, Brazil. Conception of the study.

IV Full Professor, Biostatistics Department, Universidade Santo Amaro (UNISA), Sao Paulo-SP, Brazil. Technical procedures, interpretation of data, statistical analysis.

${ }^{\vee}$ Head, Full Professor, Division of Plastic Surgery, UNIFESP. Researcher 1A-CNPq, Director Medicine III-CAPES, Sao Paulo-SP, Brazil. Intellectual, scientific, conception and design of the study; critical revision.

\begin{abstract}
Purpose: To conduct a scope review of the experimental model described by Walker and Mason, by identifying and analyzing the details of the method.

Methods: The authors searched Pubmed-Medline, Cochrane-Bireme and PEDro databases for articles published between January 2016 and December 2018, using the following search queries: burns, burn injuries, models animal, and animal experimentation. All articles whose authors used Walker and Mason's model - with or without changes to the method in Wistar rats - were included in this study.

Results: The search identified 45 mentions of Walker and Mason's model; however, after reading each summary, 20 were excluded (of which 5 due to duplicity). The inconsistencies observed after the scope review were: water temperature, length of time of exposure of the experimental model's skin to water, extent of the burnt area, and the description of the thickness/depth of the injury.

Conclusions: Reproducibility of a scientific method is the basis to prove the veracity of the observed results. Thus, it is necessary to have a greater number of publications that adopt a reproducible scientific method, for this review found inconsistencies in the description of Walker and Mason's model.
\end{abstract}

Key words: Models, Animal. Animal Experimentation. Mice. 


\section{- Introduction}

Superheated liquid is the most frequent among all causes of burns ${ }^{1-3}$. Several researches have been conducted with experimental models with hot water burns, thus making it possible to prove and improve methods and procedures, and to allow better understanding of the physiological processes that occur in the injury ${ }^{4}$.

The animal model must be as similar as possible, in functional terms, to the object of the research, as well as it is essential to constantly develop models for each disease or disorder ${ }^{4}$. The model with heated liquid typically employs a mold with an opening through which part of the animal's body is immersed in boiling water during certain amounts of time, and the depth of the burn is defined by the temperature of the agent, time of exposure and pressure of contact ${ }^{5}$.

The most utilized model used in studies is that of Walker and Mason ${ }^{6}$ : a thin asbestos metal cylinder base is cut in half longitudinally, and the extremities are welded to fix two crossed straps of heavy plastic to keep the animal immobilized at the base. The hole of the cylinder is opened and covered with rubber, the model assembly is protected with three layers of adhesive surgical tape and sprayed with a water repellent to avoid leaking of the liquid outside the preset margins. In addition, metal tacks are placed on the four extremities to attach the animal's paws, as well as clamps to hold the device by its extremity and thus maintain the exposed area immersed in boiling water for 10 seconds (s), resulting in full thickness burn. A 3 s-immersion results in partial burn.

This model, however, and due to the lack of a histological study, does not accurately describe the location of the injury. It only informs if the burn is full thickness or partial. It also does not describe in detail the protocol followed to induce the injury, on account of which some authors that used the same method made changes to it but did not describe them in their studies $^{7-12}$. The lack of accuracy and details are the reasons that led us to conduct a scope review, mapping researches made in this field and identifying possible gaps in the model.

\section{- Methods}

The study was designed as a scope review in order to map the main concepts that support a specific area of knowledge, to examine the extent, reach, and nature of the investigation, to summarize and publish its data, and to identify the gaps observed in existing studies. Studies that dealt with Walker and Mason's scalding model in
Wistar rats were analyzed, regardless of the object of such studies. The contexts of interest were any in regard to scalding models.

The authors searched Pubmed/Medline, Cochrane/ Bireme and PEDro databases for articles in Portuguese, English and/or Spanish, published between 2016 and 2018, that described experiments in animals, using burns, burn injuries, models animal, and animal experimentation as search queries.

The titles and abstracts - if available - of the 45 articles resulting from the search were read and analyzed in order to identify those that were potentially suitable for this study. In case of doubt, they were kept for the next phase, which included reading of the selected articles in full.

The authors included all articles that mentioned having employed Walker and Mason's model ${ }^{6}$, with or without changes to the method, and excluded those whose objective were not scalding burns and that did not employ Walker and Mason's method ${ }^{6}$.

Publishing data (for example, year, place and journal) and publication content type (for example, pathology and medication) were extracted. The main focuses of the proposition of the problem, and in the methods, discussions and conclusions were identified, extracted and analyzed. When necessary, the authors would reexamine the full article(s). The authors then identified analysis categories that made it possible to summarize the findings in a narrative manner.

\section{- Results}

The authors' query-based search strategies produced 45 citations with the model and/or burn descriptor, 5 of which were excluded on account of duplicity. After analyzing the titles and abstracts of the 40 articles pertaining to the query that included the descriptor "scalding", which is the object of interest of this study, the authors eliminated 15, and subsequently read the remaining 25 articles in full. Finally, 14 articles were chosen and maintained for this review for they were specifically about water scalding using Walker and Mason's model ${ }^{6}$, with or without changes to the method. Figure 1 describes the analysis flow.

\section{Objectives of the studies}

Among the 16 final remaining articles included in the review for in-depth analysis, 6 (29\%) studied some type of burn treatment and 10 (71\%) examined some item regarding the pathology itself. 


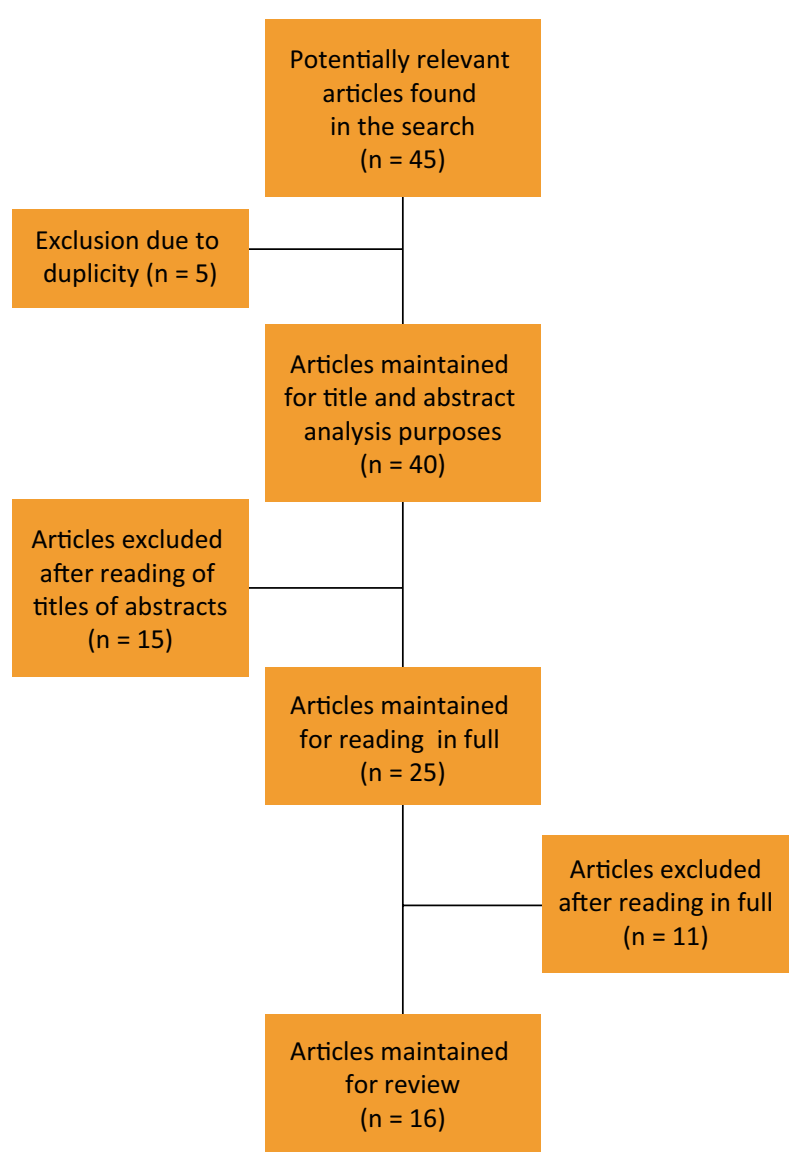

Figure 1 - Literature search and inclusion of articles.

\section{Temperature and length of exposure time}

The sum of the water temperature and the length of exposure time to water is important to determine the injury degree: in 2 studies, temperature ranged from $70^{\circ} \mathrm{C}$ to $78^{\circ} \mathrm{C}(14 \%)$; in 3 studies, from $80^{\circ} \mathrm{C}$ to $89^{\circ} \mathrm{C}$; in 3 other studies, from $90^{\circ} \mathrm{C}$ to $98^{\circ} \mathrm{C}(21 \%)$; in 4 studies, at $100^{\circ} \mathrm{C}(29 \%) ; 1$ study only mentioned boiling water (7\%); and, in 3 studies, the authors do not inform temperature or length of exposure time (21\%).

As to length of time of contact with hot water, in 2 studies it is $3 \mathrm{~s}(14 \%)$; in 6 studies, $9 \mathrm{~s}(6 \%)$; in 5 other studies, $10 \mathrm{~s}(50 \%)$; in 1 study, $17 \mathrm{~s}$ (7\%); and, in 2 other studies, $30 \mathrm{~s}(14 \%)$.

\section{Injury area}

None of the 16 studies describe the exact location, but rather use the words 'dorsal' and/or 'ventral': 2 studies mention ventral (14\%); 13 mention dorsal (85\%), and 1 study does not mention the location at all (1\%).

As to the injury area, 12 studies used the following formula: TBSA $\left(\mathrm{cm}^{2}\right)=9.1 \mathrm{BW}$ (animal's body weight in grams) /3; only Walker's study calculated the area; the other articles did not give any description (86\%), and 2 studies measured the area in $\mathrm{cm}^{2}(14 \%)$.

This is an important fact to determine the type of burn. Some studies mention degrees while others mention extent. We observed fourth degree burns in 4 studies (29\%), second degree burn in 1 study (7\%), and first degree burn in 1 other study (7\%). We also observed the terms total/partial thickness in 5 studies (36\%), and no mention of the type of burn in 3 studies (21\%).

\section{Description of the burn model}

The description of the burn inducing method is important to be able to reproduce the study. Of the studies we reviewed, 6 (43\%) inform they followed Walker and Mason's model ${ }^{6]}$, but did not inform if they did or not make changes to the model. On the other hand, 8 studies inform having made changes to the model, but do not describe the changes made (57\%) (Table 1).

Table 1 - Description of te burn model.

\begin{tabular}{|c|c|c|c|c|c|}
\hline Author & Objective & $\begin{array}{l}\text { Length of } \\
\text { Time }\end{array}$ & $\begin{array}{l}\text { Area of } \\
\text { Injury }\end{array}$ & Temperature & Type of burn \\
\hline Anderson et al. ${ }^{13}$ & $\begin{array}{l}\text { Demonstrate the role of chromium in } \\
\text { response to severe burn }\end{array}$ & - & $20 \%$ & - & $\begin{array}{l}\text { 3rd degree } \\
\text { burn }\end{array}$ \\
\hline Bortolin et al. ${ }^{14}$ & $\begin{array}{c}\text { Burn injury induces histopathological } \\
\text { changes in liver of rats }\end{array}$ & $\begin{array}{l}10 \mathrm{~s} \\
3 \mathrm{~s}\end{array}$ & $\begin{array}{l}30 \% \text { Dorsal } \\
15 \% \text { Ventral }\end{array}$ & $87^{\circ} \mathrm{C}$ & - \\
\hline Canhão et al. ${ }^{15}$ & $\begin{array}{l}\text { Effects of mesalamine treatment on gut } \\
\text { barrier integrity after burn injury }\end{array}$ & $\begin{array}{l}7 \mathrm{~s} \\
9 \mathrm{~s}\end{array}$ & $20 \%$ & $\begin{array}{l}85^{\circ} \mathrm{C} \\
95^{\circ} \mathrm{C}\end{array}$ & $\begin{array}{l}\text { Full thickness } \\
\text { 3rd degree burn }\end{array}$ \\
\hline Li et al. ${ }^{16}$ & $\begin{array}{c}\text { Auricular vagal nerve stimulation } \\
\text { ameliorates burn-induced gastric } \\
\text { dysmotility via sympathetic-COX-2 } \\
\text { pathways in rats }\end{array}$ & $\begin{array}{l}10 \mathrm{~s} \\
3 \mathrm{~s}\end{array}$ & $\begin{array}{l}60 \% \\
\text { Dorsal } \\
\text { Ventral }\end{array}$ & $95^{\circ} \mathrm{C}$ & 3rd degree burn \\
\hline
\end{tabular}




\begin{tabular}{|c|c|c|c|c|c|}
\hline Ida et al. ${ }^{17}$ & $\begin{array}{c}\text { Burn depth assessments by } \\
\text { photoacoustic imaging and laser } \\
\text { Doppler imaging }\end{array}$ & $10 \mathrm{~s}$ & $\begin{array}{l}4 \times 10 \mathrm{~cm}^{2} \\
\text { Dorsal }\end{array}$ & $\begin{array}{l}70^{\circ} \mathrm{C} \\
78^{\circ} \mathrm{C}, 83^{\circ} \mathrm{C} \\
88^{\circ} \mathrm{C}, 93^{\circ} \mathrm{C} \\
98^{\circ} \mathrm{C}\end{array}$ & $\begin{array}{l}\text { Superficial dermal } \\
\text { burn, deep } \\
\text { dermal burn, and } \\
\text { deep burn }\end{array}$ \\
\hline Hoscheit et al. ${ }^{18}$ & $\begin{array}{c}\text { Burn injury has skeletal site-specific } \\
\text { effects on bone integrity and markers } \\
\text { of bone remodeling }\end{array}$ & $30 \mathrm{~s}$ & $\begin{array}{l}30 \% \\
\text { Dorsal }\end{array}$ & $100^{\circ} \mathrm{C}$ & 4th degree burn \\
\hline Mesquita et al. ${ }^{19}$ & $\begin{array}{l}\text { Effect of low-intensity therapeutic } \\
\text { ultrasound on wound healing in rats } \\
\text { subjected to third degree burns }\end{array}$ & $10 \mathrm{~s}$ & $\begin{array}{l}30 \% \\
\text { Dorsal }\end{array}$ & $100^{\circ} \mathrm{C}$ & 3rd degree burn \\
\hline Vana et al. ${ }^{20}$ & Proteasome inhibition after burn injury & $17 \mathrm{~s}$ & $\begin{array}{l}30-40 \% \\
\text { dorsal }\end{array}$ & Boiling water & 4th degree burn \\
\hline Tian et al. ${ }^{21}$ & $\begin{array}{c}\text { The relationship between inflammation } \\
\text { and impaired wound healing in a } \\
\text { diabetic rat burn model }\end{array}$ & $8 \mathrm{~s}$ & $\begin{array}{l}10 \% \\
\text { Dorsal }\end{array}$ & $70^{\circ} \mathrm{C}$ & 2nd degree burn \\
\hline Wiggins-Dohlvik et al. ${ }^{22}$ & $\begin{array}{c}\text { Investigate microvascular abnormalities } \\
\text { and changes in permeability associated } \\
\text { with burn trauma }\end{array}$ & $30 \%$ dorsal & $10 \mathrm{~s}$ & $100^{\circ} \mathrm{C}$ & - \\
\hline Al-Roujayee 23 & $\begin{array}{c}\text { Evaluate the effect of the phenolic } \\
\text { compound naringenin on thermal } \\
\text { burn-induced inflammatory responses } \\
\text { and oxidative stress }\end{array}$ & $10 \mathrm{~s}$ & $\begin{array}{c}20 \% \\
\text { Area: } 6 \mathrm{~cm}^{2}\end{array}$ & $90^{\circ} \mathrm{C}$ & $\begin{array}{l}\text { 1st degree burns } \\
\text { with partial skin } \\
\text { injury }\end{array}$ \\
\hline Koami et al. ${ }^{24}$ & $\begin{array}{l}\text { Haptoglobin reduces inflammatory } \\
\text { cytokine INF-y and facilitates clot } \\
\text { formation in acute severe burn model }\end{array}$ & - & $\begin{array}{l}30 \% \\
\text { Dorsal }\end{array}$ & - & 4th degree burn \\
\hline $\begin{array}{l}\text { Wiggins-Dohlvik; } \\
\text { Tharakan }{ }^{25}\end{array}$ & $\begin{array}{l}\text { A rat burn injury model for studying } \\
\text { changes in microvascular permeability }\end{array}$ & $10 \mathrm{~s}$ & $30 \%$ & $100^{\circ} \mathrm{C}$ & - \\
\hline Ida et al. ${ }^{26}$ & $\begin{array}{c}\text { Lensless high-resolution photoacoustic } \\
\text { imaging scanner for in vivo skin } \\
\text { imaging }\end{array}$ & - & - & - & $\begin{array}{l}\text { Deep dermal burn } \\
\text { and deep burn }\end{array}$ \\
\hline
\end{tabular}

The inconsistencies observed after the scope review were: water temperature, length of time of contact of the experimental model's skin with water, calculation of the extent of the burnt area and description of the thickness of the injury.

\section{- Discussion}

Scalding burns are extremely damaging wounds that disproportionately affect people in developing countries, such as Brazil, where great part of the population lives in unsafe conditions and access to burn treatment is limited. Children up to age 6 are constant victims of scalding/ hot liquids and combustion (chemical) burns, the majority of which are domestic accidents, and represent $60 \%$ of the cases. Not only the mortality rate is very high, but also the survivors are burdened with physical and emotional scars for the rest of their lives. The etiology and nature of the injuries caused by scalding burns are different from other causes of burns. Many treatments are controversial and the costs are extremely high. Treatment and management of a scalding burn victim require well trained professionals that are fully aware of the etiology and have access to proper equipment and materials. A burn victim is a challenge for all health professionals, and their continuous improvement in the area is necessary ${ }^{27,28}$.

Walker and Mason ${ }^{6}$ created and described the first scalding model, which is still used by researchers, with or without changes. When changes are made to an experimental model, it is extremely important to provide a detailed description of the changes in order to help reproduce the study. In the last years, there has been a small but constant increase in the number of studies/articles about burns, most of which are original articles published in surgical medical journals. These publications were not financially influenced, great part of them was produced in universities, and English is the idiom mostly used to write these articles ${ }^{27,28}$.

Walker and Mason ${ }^{6}$ used $100^{\circ} \mathrm{C}$ as water temperature and 4 studies ${ }^{18,19,22,25}$ did the same. More recent studies ${ }^{16,17,23}$ used $90^{\circ} \mathrm{C}$ to $98^{\circ} \mathrm{C}$ as water temperatures, yet, the results were the same as those using $100^{\circ} \mathrm{C} ; 2$ studies ${ }^{[17,21]}$ used $70^{\circ} \mathrm{C}$ to $78^{\circ} \mathrm{C}$ so as to obtain a more superficial injury; and 3 studies ${ }^{14,15,17}$ used $80^{\circ} \mathrm{C}$ a $89^{\circ} \mathrm{C}$ and observed a median injury. The sum of the water temperature and the length of exposure time to the water are important to determine the degree of the injury. Vana et al..$^{20}$ only mention 'boiling water', which 
is relative, for the boiling point of water depends on the altitude of the environment. Three studies ${ }^{13,24,26} \mathrm{did}$ not inform the temperature and the length of exposure time to water; therefore, they are not reproducible. As already mentioned above, in order to determine the depth of the injury, it is necessary to associate the water temperature with the length of exposure time of the animal's skin to it. Walker and Mason ${ }^{[6]}$ used three different lengths of time $-3,5$ and 10 seconds - to obtain three types of injury depth. Two studies $^{14,16}$ used 3 seconds and observed a superficial (first degree) burn, which is consistent with the original study. Canhão et al..$^{15}$ used 7 to 9 seconds to obtain a median injury (second degree); however, Walker and Mason ${ }^{6}$ observed the same result using 4 seconds. In order to observe a full thickness burn (third degree), 7 studies used the same amount of seconds as Walker and Mason, i.e., 10 seconds ${ }^{14,16,17,19,22,23,25}$. Vana et al. ${ }^{20}$ used 16 seconds and Hoscheit et al. ${ }^{18} 30$ seconds. All the authors mentioned having observed deep and severe injury using $>10$ seconds.

The location and size of the injury depend on the objective of the study, but it is essential to accurately describe the location and the formula used to obtain the size of the injury in order to reproduce the model. No study included in this review described precisely how the location of the injury was obtained as did Walker and Mason ${ }^{6}$, only described as dorsal, without providing details of where on the dorsal area ${ }^{14,16-22,24}$. Bortolin et al. ${ }^{14}$ and Li et al. ${ }^{16}$ informed the location as ventral, but without further details in order to allow reproducibility.

All aspects of a study must be fully described in order to make it reproducible. We did find two circumstances in studies that followed Walker and Mason's model'; however, the authors did not inform if they made changes to the model|13,14,19,20,23. In reading the articles in full, we noticed changes in temperature, location and injury extent. We also read studies that confirm having made changes to the model, but do not mention what kind of changes were made $15-18,21,24-26$, thus making it impossible to reproduce the model.

\section{- Conclusions}

Reproducibility of a scientific method is the basis to prove the veracity of the observed results. Thus, it is necessary to have a greater number of publications that adopt a reproducible scientific method, for this review found inconsistencies in the description of Walker and Mason's model.

\section{- References}

1. Balan MAJ, Oliveira MLF, Trassi G. Características das vítimas de queimaduras atendidas em unidade de emergência de um hospital escola do noroeste do Paraná. Ciênc Cuid Saúde. 2009;8(2):169-75. doi: 10.4025/cienccuidsaude. v8i2.8195.

2. Vendrusculo MT, Balieiro BRC, Guanilo EEM, Junior FAJ, Rossi AL. Burns in the domestic environment: Characteristics and circumstances of accidents. Rev Latinoam Enferm. 2010;18(3):444-51. doi: 10.1590/s0104-11692010000300021.

3. Cruz BF, Cordovil PBL, Batista KNM. Perfil epidemiológico de pacientes que sofreram queimaduras no Brasil: revisão de literatura. Rev Bras Queimaduras. 2012;11(4):246-50. doi: 10.25248/REAS57_2017.

4. Ferreira LM, Hochman B, Barbosa MV. Experimental models in research. Acta Cir Bras. 2005;20(2):28-34. doi: S0102-86502005000800008.

5. Venter NG, Monte-Alto-Costa A, Marques RG. A new model for the standardization of experimental burn wounds. Burns. 2015;41(3):542-7. doi:10.1016/j. queimaduras.2014.08.002.

6. Walker HL, Mason Jr AD. A standard animal burn. J Trauma. 1968;8(1):1049-51. doi: 10.1097/00005373196811000-00006.

7. Santos Heredero FX, Hamann C, Obispo MJM, Rodriguez C, Coca MS. Experimental burn models. Ann Burns Fire Dis. 1996;9(2):96-100.

8. Kim DE, Phillips TM, Jeng JC, Rizzo AG, Roth RT, Stanford JL, Jablonski KA, Jordan MH. Microvascular assessment of burn depth conversion during varying resuscitation conditions. J Burn Care Rehabil. 2001;22:406-16. PMID: 11761393.

9. Shi Z, Li C, Li C. The effect of air pressure on edema and healing of scalded tissue of rats. J Burn Care Res. 2007;28(2):286-90. doi: 10.1097/BCR.0B013E318031A195.

10. Orgaes FAFS, Lyra MC, Rodrigues Junior OF, Gonella HA. Estudo histopatológico do uso de heparina tópica em queimaduras por escaldo em ratos. Rev Soc Bras Cir Plást. 2007;22(1):39-44.

11. Meyerholz D, Piester LT, Sokolich JC, Gideon K, Zamba D, Ligh TD. Morphological parameters for assessment of burn severity in an acute burn injury rat model. Int J Exp Pathol. 2009;90:26-33. doi: 10.1111/j.1365-2613.2008.00617.x.

12. Ezzati A, Bayat M, Taheri S, Mohsenifar Z. Low-level laser therapy with pulsed infrared laser accelerates thirddegree burn healing process in rats. J Rehabil Res Dev. 2009;46(4):543-54. PMID: 19882488.

13. Anderson RA, Bryden C, Agay NA, Chancerelle C, Polansky $\mathrm{Y}$, Roussel MM. Burn-induced alterations of chromium and the glucose/insulin system in rats. Burns. 2006;32:46-51. doi: 10.1016 / j.burns.2005.08.005.

14. Bortolin JA, Quintana HT, Tomé TC, Ribeiro FAD, Ribeiro DA, Oliveira F. Burn injury induces histopathological changes and cell proliferation in liver of rats. World J Hepatol. 2016;8(6):322-30. doi: 10.4254 / wjh.v8.i6.322

15. Canhão AR, Akhtar S, Hammer AM, Morris NL, Javorski MJ, Li X, Kennedy RH, Gamelli RL, Choudhry MA. Effects of mesalamine treatment on gut barrier integrity after burn injury. J Burn Care Res. 2016;1559:283-92. doi: 10.1097/ BCR.0000000000000396. 
16. Li H1, Yin J, Zhang Z, Winston JH, Shi XZ, Chen JD. Auricular vagal nerve stimulation ameliorates burn-induced gastric dysmotility via sympathetic-COX-2 pathways in rats. Neurogastroenterol Motil. 2016;29(1);36-42. doi: 10.1111/ nmo.12693.

17. Ida $T$, Iwazaki $H$, Kawaguchi $Y$, Kawauchi S, Ohkura T, Iwaya K, Tsuda H, Saitoh D, Sato S, Iwai T. Burn depth assessments by photoacoustic imaging and laser Doppler imaging. Wound Rep Reg. 2016;24:349-55. doi: 10.1111/wrr.12374.

18. Hoscheit M, Conner G, Roemer J, Vuckovska A, Abbasnia $P$, Vana P. Burn injury has skeletal site-specific effects on bone integrity and markers of bone remodeling. J Burn Care Res. 2016;37(6):367-78. doi: 10.1097/ BCR.0000000000000389.

19. Mesquita RL, Silva PIC, Sawaki SH, Oliveira K, FontesPereira AJ, Silva-Freitas JJ, Albuquerque-Pereira WCl, Kietzer KC. Effect of low-intensity therapeutic ultrasound on wound healing in rats subjected to third degree burns. Acta Cir Bras. 2016;31(1):36-43. doi: 10.1590/S0102865020160010000006.

20. Vana PG, LaPorte HM, Wong YM, Kennedy RH, Gamelli $\mathrm{RL}$, Majetschak M. Proteasome inhibition after burn injury. J Burn Care Res. 2016;37(4):207-15. doi: 10.1097/ BCR.0000000000000280.

21. Tian M, Qing C, Niu Y, Dong J, Cao X, Song F, Ji X, Lu S. The relationship between inflammation and impaired wound healing in a diabetic rat burn model. J Burn Care Res. 2016;47:115-24. doi: 10.1097/BCR.0000000000000171.
22. Wiggins-Dohlvik K, Oakley RP, Han MS, Stagg HW, Alluri $H$, Shaji CA, Davis ML, Tharakan B. Binu Tharakan. Tissue inhibitor of metalloproteinase-2 inhibits burn-induced derangements and hyperpermeability in microvascular endothelial cells. Am J Surg. 2016;211:197-205. doi: 10.1016/j.amjsurg.2015.08.016.

23. Al-Roujayee AS. Naringenin improves the healing process of thermally-induced skin damage in rats. J Inter Med Res. 2017;45:570-82. doi: 10.1177/0300060517692483.

24. Koami K, SakamotoY, Miyasho T, Noguchi R, Sato N, Kai K, Yamada KC, Inoue S. Haptoglobin reduces inflammatory cytokine INF- $\gamma$ and facilitates clot formation in acute severe burn rat model. J Nippon Med Sch. 2017;84(2):64-72. doi: 10.1272 / jnms.84.64.

25. Wiggins-Dohlvik K, Tharakan B. A rat burn injury model for studying changes in microvascular permeability. Humana Press Inc. 2018;1717:93-100. doi: 10.1007 / 978-1-4939-7526-6_8.

26. Ida T, Iwazaki H, Omuro T, Kawaguchi Y, Tsunoi Y, Kawauchi S, Sato S. Lensless high-resolution photoacoustic imaging scanner for in vivo skin imaging. Opt Rev. 2018;25:33-9. doi: 10.1007/s10043-017-0384-1.

27. lurk LK, Oliveira AF, Gragnani A, Ferreira LM. Evidencebased medicine in burns treatment. Rev Bras Queimaduras. 2010;9(3):95-9.

28. Dissanaike S, Rahimi M. Epidemiology of burn injuries: highlighting cultural and socio-demographic aspects. Int Rev Psychiatry. 2009;21(6):505-11. doi: 10.3109/09540260903340865.

\section{Correspondence:}

Taís Amadio Menegat

Rua Regino Aragão, 65/41

04285-020 São Paulo - SP Brasil

tamadiomenegat@gmail.com

Received: June 05, 2019

Review: Aug 09, 2219

Accepted: Sept 07, 2019
Conflict of interest: none

Financial source: none

This is an Open Access article distributed under the terms of the Creative Commons Attribution License, which permits unrestricted use, distribution

and reproduction in any medium, provided the original work is properly cited.

${ }^{1}$ Research performed at Division of Plastic Surgery, Department of Surgery, Universidade Federal de São Paulo (UNIFESP), Brazil. 